\title{
WATER-SOLUBLE NUTRIENTS IN AERIAL PLANT PARTS OF PEANUT AND WHITE OAT AS AFFECTED BY LIME AND GYPSUM APPLICATION ${ }^{(1)}$
}

\author{
Rúbia Renata Marques ${ }^{(2)}$, Carlos Alexandre Costa Crusciol ${ }^{(3)}$, \\ Gustavo Spadotti Amaral Castro ${ }^{(4)}$ \& Lucas Perim( ${ }^{(4)}$
}

\begin{abstract}
SUMMARY
Lime and gypsum influence nutrient availability and uptake, as well as the content of organic acids in the aerial plant parts. These changes, quantified by plant analysis of soluble nutrients, may potentiate the effect of soil amendment, ensuring the sustainability of the no-tillage system. In this sense the effect of lime and gypsum surface application on the content of water-soluble nutrients in peanut and oat residues was evaluated. The experiment was conducted on an Oxisol in Botucatu (SP) in the growing seasons 2004/2005 and 2005/2006. It was arranged in a randomized block design in split plots with four replications, where lime rates represented the plots and presence or absence of gypsum application the subplots. Peanut was grown in summer and white oat in the winter in the entire experimental area. Gypsum applied to peanut increased soluble Ca only in the first season, due to the short period between product application and determination of soluble nutrient contents in the plant extract. Liming of peanut and oat increased soluble $\mathrm{Ca}, \mathrm{Mg}, \mathrm{K}$ contents, did not alter $\mathrm{Cu}$ content and reduced $\mathrm{Zn}, \mathrm{Mn}$ and $\mathrm{Fe}$ contents in both years of cultivation. Gypsum on the other hand reduced the electrical conductivity of peanut (2004/2005 and 2005/2006) and white oat (2004/2005).
\end{abstract}

Index terms: plant residues, acidity, nutrient mobility.

\footnotetext{
(1) Part of the thesis (doctorate) of the first author apresentada à Faculdade de Ciências Agronômicas, Universidade Estadual Paulista - FCA/UNESP. Received for publication in June 2009 and approved in October 2010.

(2) Lecturer in Agronomy, Universidade Católica Dom Bosco - UCDB. CEP 79117-900 Campo Grande (MS). Coordenadora do Curso de Agronomia. E-mail: rubiarmarques@hotmail.com

(3) Assistant professor at the Department of Plant Production of the Faculdade de Ciências Agronômicas, Universidade Estadual Paulista - FCA/UNESP. Campus de Botucatu, Caixa Postal 237, CEP 18603-970 Botucatu (SP). CNPq stipendiary. E-mail: crusciol@fca.unesp.br CNPq. E-mail: crusciol@fca.unesp.br

${ }^{(4)}$ Post-Graduate student in Agronomy - Agriculture. Department of Plant Production , FCA/UNESP. E-mails: gsacastro@fca.unesp.br; lperim@fca.unesp.br
} 


\title{
RESUMO: REFLEXO DA CALAGEM E GESSAGEM SUPERFICIAIS NA CONCENTRAÇÃO DE NUTRIENTES SOLÚVEIS EMÁGUA NA PARTE AÉREA DE AMENDOIM E AVEIA-BRANCA
}

\begin{abstract}
A calagem e a gessagem influenciam a disponibilidade e a absorção de nutrientes, podendo alterar a quantidade de ácidos orgânicos na parte aérea das culturas. Essas alterações, quantificadas por meio da análise de nutrientes solúveis em água, podem potencializar o efeito da correção do solo, garantindo a sustentabilidade do sistema de semeadura direta. Nesse sentido, objetivou-se avaliar o efeito da aplicação superficial de calcário e gesso no teor de nutientes solúveis em água nos resíduos vegetais das culturas de amendoim e aveia-branca. O experimento foi realizado em Latossolo Vermelho distroférrico em Botucatu (SP), nos anos agrícolas de 2004/2005 e 2005/2006. O delineamento experimental foi em blocos casualizados em esquema de parcelas subdivididas, com quatro repetições, em que as parcelas foram constituídas por doses de calcário, e as subparcelas, pela presença ou ausência da aplicação de gesso. Foi cultivado amendoim no verão e aveia-branca no inverno, em toda a área experimental. Na cultura do amendoim a aplicação de gesso elevou os teores de Ca solúvel em água apenas na primeira safra, em razão do curto período entre a aplicação do produto e a determinação dos teores de nutientes solúveis no extrato vegetal da cultura. A calagem realizada nas culturas de amendoim e aveia-branca elevou os teores solúveis de Ca, $\mathrm{Mg}, \mathrm{K}$ e não alterou o teor de Cu e reduziu os teores de Zn, Mn e Fe nos dois anos de cultivo. Já a gessagem reduziu os valores da condutividade elétrica do amendoim (2004/2005 e 2005/2006) e da aveia-branca (2004/ 2005).
\end{abstract}

Termos de indexação: resíduos de plantas, acidez, mobilidade de nutientes.

\section{INTRODUCTION}

Plant residues play an important role in the chemical behavior of acidic soils, neutralizing acidity, reducing $\mathrm{Al}$ toxicity and favoring the movement of cations in the soil ((Franchini et al., 1999a,b; 2001, 2003; Meda et al., 2001; Myazawa et al., 2002; Soratto $\&$ Crusciol, 2007). To determine the contents of watersoluble cations based on plant extracts is one of the most recommended chemical methods of quality assessment of plant residues, since it indicates the intensity at which the above phenomena may occur. Franchini et al. $(2001,2003)$ observed that the capacity of plant waste to mobilize cations in acid soils is related to the content of low-molecular-weight organic acids such as citric, malic and t-aconitic acids.

In plants, low-molecular-weight organic acids are found in the form of organic anions. By the uptake of basic cations they maintain the chemical electroneutrality (Pierre \& Banwart, 1973). Moreover, despite the existence of inorganic anions $\left(\mathrm{NO}_{3}^{-}, \mathrm{SO}_{4}{ }^{2-}\right.$, $\mathrm{H}_{2} \mathrm{PO}_{4}^{-}$, and $\mathrm{Cl}$ ) in plant tissue, the contents are insignificant. Thus, since the determination of basic reaction nutrients in plant tissue is relatively easier than that of organic anions, the sum of these is one of the best indicators of the effects of waste on the solution chemistry of acid soils (Franchini et al., 1999a; Meda et al., 2001; Cassiolato et al., 2002). Thus, the sum of soluble cations can indicate the potential for mobilization of cations and the quantities of $\mathrm{H}$ and $\mathrm{Al}^{3+}$ that can be neutralized through plant residues, correlating with the effects of plant material to increase $\mathrm{pH}$ and exchangeable $\mathrm{Ca}$ and decrease soil exchangeable $\mathrm{Al}$ (Franchini et al., 1999a; Meda et al., 2001; Cassiolato et al., 2002), since $\mathrm{Ca}, \mathrm{Mg}, \mathrm{K}, \mathrm{Na}$, and $\mathrm{Mn}$ bound in organic compounds are replaced by $\mathrm{H}$ and $\mathrm{Al}^{3+}$ to form stable protonated compounds or organic $\mathrm{Al}$ - complexes (Miyazawa et al., 2000).

It is well-known that lime and gypsum application influence soil nutrient availability and plant nutrient uptake, either by the direct application of $\mathrm{Ca}, \mathrm{Mg}$ and $\mathrm{S}$ or by chemical modifications induced by soil application of these products. This is particularly true in the case of lime in relation to the $\mathrm{pH}$, which may lead to changes in the nutrient contents found in soluble form in plants. Soratto \& Crusciol, (2007) evaluated the effects of lime and gypsum surface application on annual crops and observed changes in the contents of soluble nutrients in the aerial plant parts of the plants. According to these authors, liming increased the contents of soluble nutrients and sum of cations. Gypsum on the other hand increased $\mathrm{Ca}$ contents and reduced contents of soluble $\mathrm{Mg}$ in the aerial parts of rice, oat and bean at flowering.

Studies on the influence of lime and gypsum surface application on the contents of water-soluble basic reaction nutrients in various crops, e.g., oat and peanut, which are important alternatives for agricultural diversification and expansion of crop rotation, are scarce in the literature. The objective of this study was to evaluate the effect of surface application of lime and gypsum based on the contents of water-soluble nutrients in the aerial plant parts of peanut and oat. 


\section{MATERIAL AND METHODS}

This study was conducted in the 2004/2005 and 2005/2006 growing seasons on the experimental farm Lageado of the Faculty of Agronomic Sciences UNESP, located in Botucatu (SP) (long. $48^{\circ} 23^{\prime}$ W, lat. $22^{\circ} 51$ ' S, $765 \mathrm{~m}$ asl). According to Köppen, the regional prevailing tropical altitude climate is Cwa, with dry winters and hot and rainy summers (Lombardi Neto \& Drugowich, 1994). The soil of the experimental area was classified as Rhodic Ferralsol (FAO, 2006). In August 2004 the soil was sampled in the $0-0.20 \mathrm{~m}$ layer and chemically analyzed to calculate lime requirement, according to Raij et al. (2001) with the following results: organic matter $27.3 \mathrm{~g} \mathrm{dm}^{-3}, \mathrm{pH}\left(\mathrm{CaCl}_{2}\right) 4.9, \mathrm{P}$ (resin) $35.1 \mathrm{mg} \mathrm{dm}^{-3}$, $\mathrm{K}, \mathrm{Ca}, \mathrm{Mg}$ and CEC 1.1, 24.0, 10.0 and $70.0 \mathrm{mmol}_{\mathrm{c}} \mathrm{dm}^{-3}$, respectively, and $\mathrm{V} \%=50 \%$. The sand, silt and clay contents were, respectively, 545, 108 and $347 \mathrm{~g} \mathrm{~kg}^{-1}$. The same treatments (lime and gypsum) had been applied in the area since 2002 ; the rotation consisted of rice - black oat - common bean - black oat. After the harvest millet was sown for biomass production, according to the guidelines of no-tillage.

The experiment was arranged in a randomized block design in split plots with four replications. The plots $(5.4 \times 18 \mathrm{~m})$ consisted of four lime rates $(0,1,000$, 2,000 and $4,000 \mathrm{~kg} \mathrm{ha}^{-1}$ - lime requirement -), containing $23.3 \% \mathrm{CaO}, 17.5 \% \mathrm{MgO}$ and $71 \%$ ECC. Lime rates were determined to increase base saturation to $70 \%$, based on the soil chemical analysis in the $0-0.20 \mathrm{~m}$ layer. The subplots were represented by the application or not of 2,100 $\mathrm{kg} \mathrm{ha}^{-1}$ gypsum $(6 \mathrm{x}$ clay content in $\mathrm{g} \mathrm{kg}^{-1}$, in the $0.20-0.40 \mathrm{~m}$ layer), containing $20 \% \mathrm{CaO}$ and $16 \% \mathrm{~S}$. The plots of $48.6 \mathrm{~m}^{2}$ $(5.4 \times 9.0 \mathrm{~m})$ were spaced $8.0 \mathrm{~m}$ and the blocks $3.0 \mathrm{~m}$ away from each other. To ensure the uniformity of the evaluated area, one row on each side and $0.5 \mathrm{~m}$ on either end of the subplots were excluded. The area between blocks and plots was kept bare in the spaces.

Lime was applied to the plot surface on November 19, 2004, without incorporation, on top of millet residue. Gypsum was surface applied on the same day, to half the limed plots, representing subplots.
On November 22, 2004, and November 30, 2005, the peanut cultivar (Arachis hipogaea L.) Runner IAC 886 was sown in all plots. Approximately 12 viable, insecticide-treated seeds ( $150 \mathrm{~g}$ of thiamethoxan per $100 \mathrm{~kg}$ of seeds) were sown per meter, in rows spaced $0.80 \mathrm{~m}$ apart. Fertilization at sowing in both years of cultivation consisted of $300 \mathrm{~kg} \mathrm{ha}^{-1}$ of NPK fertilizer (8-28-16) $+10 \%$ Sand $0.5 \% \mathrm{Zn}$, as indicated by soil analysis and recommendations of Ambrosano et al. (1996).

After peanut harvest in both growing seasons white oat (Avena sativa L.) cultivar "IAC 7" was sown on 7 April 2005, and 20 April 2006, in the whole experimental area, spaced $0.17 \mathrm{~m}$ apart at a density of 60 viable seeds per meter in 26 plots consisting of $9 \mathrm{~m}$ long rows. Fertilization at sowing consisted of $200 \mathrm{~kg} \mathrm{ha}^{-1}$ of NPK fertilizer (04-20-10) + 7.0 \% S in both years of cultivation, based on soil analysis and according to the recommendations of Camargo et al. (1996).

After harvesting the second white oat crop in November 2006, i.e, 24 months after lime and gypsum application, samples were taken from the $0-0.20 \mathrm{~m}$ layer for chemical analysis. Seven sub-samples were collected in the evaluation area from each subplot, to form a composite sample, using a soil core sampler. The samples were analyzed to determine $\mathrm{pH}\left(\mathrm{CaCl}_{2}\right)$, $\mathrm{Al}^{3+}, \mathrm{Ca}^{2+}, \mathrm{Mg}^{2+}$ and $\mathrm{K}^{+}$, according to Raij et al. (2001) (Table 1).

At flowering in both growing seasons, 10 plants per plot were collected in the case of peanut and in the case of white oat, the aerial parts of plants growing in $2 \mathrm{~m}$ of the row of each subplot. The plants were cut at ground content, wrapped in labeled paper bags for transport to a forced-air oven and dried to constant weight at $65^{\circ} \mathrm{C}$. Later the samples were ground and the quality of plant residues analyzed by methods described by Miyazawa et al. (2000) and Meda et al. (2002b).

The $\mathrm{Ca}, \mathrm{Mg}, \mathrm{K}, \mathrm{Cu}, \mathrm{Zn}, \mathrm{Fe}$, and $\mathrm{Mn}$ contents in the plant extracts were determined by inductively coupled plasma optical emission spectroscopy (ICPOES). In the plant extract, the electrical conductivity (EC) was also determined in the solution, as proposed by Miyazawa et al. (2000).

Table 1. Chemical soil analysis of samples collected in the 0-20 cm layer, 24 months after lime and gypsum surface application

\begin{tabular}{|c|c|c|c|c|c|c|c|c|c|c|}
\hline \multirow{2}{*}{ Treatment } & \multicolumn{2}{|c|}{$\mathrm{pH} \mathrm{CaCl}_{2}$} & \multicolumn{2}{|c|}{$\mathrm{Al}^{3+}$} & \multicolumn{2}{|c|}{$\mathrm{Ca}^{2+}$} & \multicolumn{2}{|c|}{$\mathrm{Mg}^{2+}$} & \multicolumn{2}{|c|}{$\mathbf{K}^{+}$} \\
\hline & $G^{(1)}$ & no $G^{(2)}$ & $\mathbf{G}$ & no $G$ & $\mathbf{G}$ & no $G$ & $\mathbf{G}$ & no $G$ & G & no $G$ \\
\hline \multicolumn{3}{|l|}{$\mathrm{kg} \mathrm{ha}^{-1}$} & \multicolumn{6}{|c|}{$-\mathrm{mmol}_{\mathrm{c}} \mathrm{dm}^{-3}$} & & \\
\hline 0 & 4.5 & 4.5 & 4.1 & 4.7 & 18 & 9 & 5.3 & 8.9 & 0.9 & 0.9 \\
\hline 1000 & 4.8 & 4.7 & 3.7 & 3.7 & 23 & 11 & 7.4 & 11.2 & 1.4 & 1.2 \\
\hline 2000 & 5.0 & 5.0 & 2.9 & 3.2 & 31 & 14 & 10.4 & 14.4 & 2.4 & 1.9 \\
\hline 4000 & 5.8 & 5.6 & 1.4 & 1.9 & 44 & 22 & 13.4 & 22.1 & 1.2 & 1.3 \\
\hline
\end{tabular}

(1) With gypsum. ${ }^{(2)}$ Without gypsum. 
The results were subjected to analysis of variance in split-plot designs. The averages for gypsum application and crops (peanut and white oat) were compared by the $t$ test (LSD) at $5 \%$, while liming effects were evaluated by means of regression analysis at $5 \%$, by the $t$ test. The statistical program SISVAR (Ferreira, 2000) was used for the analysis.

\section{RESULTS AND DISCUSSION}

The surface application of lime and gypsum affected the soil chemical properties in the $0-0.20 \mathrm{~cm}$ layer, and liming raised $\mathrm{pH}$ and $\mathrm{Ca}^{2+}, \mathrm{Mg}^{2+}$ and $\mathrm{K}^{+}$values in the soil, further reducing $\mathrm{Al}$ toxic. Gypsum however increased soil $\mathrm{Ca}^{2+}$ and reduced $\mathrm{Mg}$ contents (Table 1).

For peanut grown in 2004/2005, it was found that gypsum application increased only the water-soluble Ca contents, in contrast with results of the 2005/06 season (Table 2), probably because the time between lime and gypsum application and sampling was short and much of the applied element was absorbed by the roots due to the higher reactivity of gypsum than of lime. There was a significant interaction between lime and gypsum for contents of soluble Ca: lime application increased $\mathrm{Ca}$ contents both in the presence and absence of gypsum. But in the presence of gypsum, a major source of $\mathrm{Ca}$, the contents of watersoluble Ca were higher, independent of the lime rate (Figure 1a,b). This confirmed the pattern indicated by soil analysis after treatment application (Table 1), which showed greater exchangeable $\mathrm{Ca}$ in soil, in agreement with the results obtained by Caires et al. (2003) and Soratto \& Crusciol (2008).

Gypsum application resulted in lower contents of water-soluble Mg in the two growing seasons (Table 2) although the other soluble cations were not affected by gypsum. Soil analysis showed reductions in the content of exchangeable $\mathrm{Mg}$ for the gypsum application (Table 1). Several studies have reported lower Mg absorption by plants as a result of gypsum surface application (Caires et al., 2003, 2004; Soratto \& Crusciol, 2007). These authors attribute the lower Mg uptake to higher leaching of the element caused by gypsum application through the formation of an ion pair with $\mathrm{SO}_{4}{ }^{2-}$. This phenomenon was reported for $\mathrm{K}$ as well, which however was not influenced, probably, by constant K fertilizations.

Gypsum application reduced the EC in crop residues (Table 2) in both growing seasons. This was due to the considerable reduction in $\mathrm{Mg}$ contents compared to the slight elevation of water-soluble $\mathrm{Ca}$ contents in the aerial parts of peanut.

Liming increased water-soluble Ca contents when applied with gypsum and increased the contents of $\mathrm{Mg}, \mathrm{K}$, and total EC, in the absence of gypsum. This finding was similar to results of Soratto \& Crusciol (2007) for black oat in the same experimental area, about 12 months after liming and gypsum surface application. These results, reinforced by soil analysis (Table 1), confirmed the hypothesis that liming is not only a source of $\mathrm{Ca}$ and $\mathrm{Mg}$, but can also increase soil K availability, probably by increasing the $\mathrm{pH}$-dependent negative charges caused by liming (Quaggio et al., 1982), reducing K leaching.

Surface liming increased the nutrient content in the extracts, mainly by increased contents of soluble $\mathrm{Ca}$ and $\mathrm{Mg}$ in the residues. Since the sum of soluble cations indicates the content of $\mathrm{H}$ and $\mathrm{Al}^{3+}$ that can be neutralized by plant residues (Miyazawa et al., 2000), surface liming can, aside from correcting soil acidity and elevated contents of soil $\mathrm{Ca}$ and $\mathrm{Mg}$ directly, improve the ability of residues to mobilize basic reaction nutrients and immobilize $\mathrm{Al}^{3+}$ in the soil solution.

Lime application did not affect water-soluble $\mathrm{Cu}$ contents in the residues, while there was a significant

Table 2. Contents of water-soluble nutrients and electrical conductivity (EC) in the plant extracts of flowering peanut as related to the surface application or non-application of gypsum in 2004/2005 and 2005/2006

\begin{tabular}{|c|c|c|c|c|c|c|c|c|c|}
\hline & Treatment & $\mathbf{C a}$ & Mg & $\mathbf{K}$ & Mn & $\mathrm{Zn}$ & $\mathrm{Cu}$ & $\mathrm{Fe}$ & EC \\
\hline \multirow{5}{*}{ 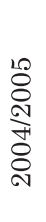 } & Gypsum & \multicolumn{7}{|c|}{$-\mathrm{mmol}_{\mathrm{c}} \mathrm{kg}^{-1}$} & $\mu \mathrm{S} \mathrm{cm}-1$ \\
\hline & Without & $146.9 \mathrm{~b}$ & $339.9 \mathrm{a}$ & 51.8 & 3.1 & 0.54 & 0.44 & 0.42 & $1.548 \mathrm{a}$ \\
\hline & With & $158.5 \mathrm{a}$ & $240.6 \mathrm{~b}$ & 53.0 & 2.9 & 0.53 & 0.46 & 0.38 & 1. $394 \mathrm{~b}$ \\
\hline & $\mathrm{CV}_{1}(\%)$ & 12.4 & 9.7 & 8.3 & 17.0 & 22.7 & 14.8 & 40.3 & 9.5 \\
\hline & $\mathrm{CV}_{2}(\%)$ & 6.8 & 8.1 & 7.9 & 22.2 & 23.2 & 16.0 & 28.1 & 5.7 \\
\hline \multirow{4}{*}{$\begin{array}{l}0 \\
8 \\
\circ \\
\stackrel{+}{0} \\
10 \\
8 \\
0 \\
0\end{array}$} & Without & 149.9 & $342.2 \mathrm{a}$ & 53.1 & 3.09 & 0.52 & 0.42 & 0.43 & $1.647 \mathrm{a}$ \\
\hline & With & 161.5 & $250.3 \mathrm{~b}$ & 54.0 & 2.89 & 0.51 & 0.43 & 0.42 & $1.558 \mathrm{~b}$ \\
\hline & $\mathrm{CV}_{1}(\%)$ & 13.0 & 11.7 & 8.2 & 10.9 & 24.3 & 19.8 & 35.5 & 9.7 \\
\hline & $\mathrm{CV}_{2}(\%)$ & 9.9 & 8.7 & 8.0 & 12.0 & 19.3 & 13.9 & 24.3 & 6.7 \\
\hline
\end{tabular}

(1) Sum. Means followed by different letters in the column differ statistically by the DMS test $(p=0.05)$. CV : $_{1}$ Coefficient of variation of the plots; $\mathrm{CV}_{2}$ : Coefficient of variation of the subplots. 

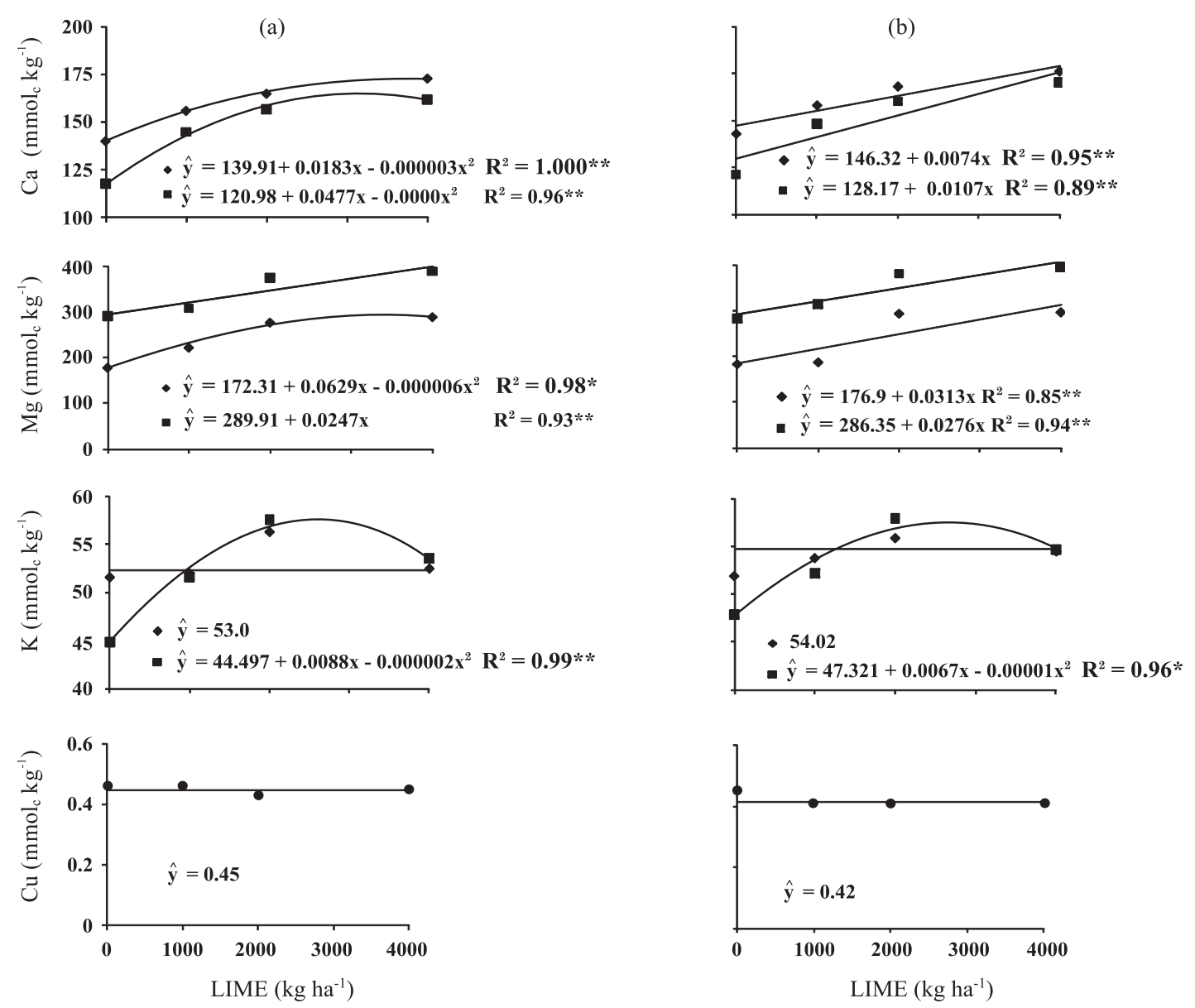

Figure 1. Contents of water-soluble calcium, magnesium, potassium and copper in extracts of flowering peanut as related to surface liming . () mean of the treatments with and without gypsum application, $(\square)$ without gypsum and ( $\diamond$ ) with gypsum in 2004/2005 (a) and 2005/2006 (b).

reduction in soluble $\mathrm{Mn}$ and Fe contents in the two growing seasons when no lime and gypsum was applied (Figures 1 and 2). The reduction in the contents of these elements can be explained by the decreasing $\mathrm{Mn}$ and $\mathrm{Fe}$ availability with increasing soil $\mathrm{pH}$ (Table 1), mainly in the surface layer (Harmsen \& Vlek, 1985), which contains most of the crop root system.

Zinc contents in the extract were reduced by liming. In the 2004/2005 growing season (Figure 2) reduction was observed when lime was applied separately, and in the 2005/2006 season (Figure 2) the water-soluble $\mathrm{Zn}$ contents in the residue decreased, independent of application or non-application of gypsum. These results can be explained by competitive inhibition of $\mathrm{Ca}$ and $\mathrm{Zn}$ (Galon et al., 1996), caused by gypsum application and liming.

There was a significant effect of interaction between lime and gypsum application (Figure 2) on peanut in both seasons, which induced a linear increase in EC, indicating a positive correlation between the sum of basic reaction nutrients (Miyazawa et al ., 2000), and water-soluble nutrient contents in crop residues, particularly of $\mathrm{Ca}$ and $\mathrm{Mg}$.
As in peanut, gypsum surface application to white oat also decreased the water-soluble $\mathrm{Mg}$ content in plant residues in both growing seasons. Differences were observed in EC of the extract in the second growing season only (Table 3 ). The values differed from those reported by Menegale et al. (2008) who studied the effect of liming on white oat. These authors obtained a higher content of water-soluble $\mathrm{Ca}$ and $\mathrm{K}$, resulting in a higher EC of the plant extract. They concluded that liming increased plant water-soluble $\mathrm{Ca}$ and $\mathrm{Mg}$ compared to the control.

Gypsum significantly reduced soluble Fe contents in white oat residues in the 2006 growing season (Table 3). This can be explained by the reduced Fe availability due to the increased soil pH (Harmsen \& Vlek, 1985) (Table 1).

There was significant lime-gypsum interaction for $\mathrm{Ca}, \mathrm{Mg}, \mathrm{K}$ content in the plant extracts in the 2005 growing season (Figure 3 ).

In the second year of white oat, liming alone provided an increase in water-soluble $\mathrm{Ca}, \mathrm{Mg}, \mathrm{K}$ in the oat plant extracts (Figures 3 and 4). The application of lime rates and gypsum probably elevated 

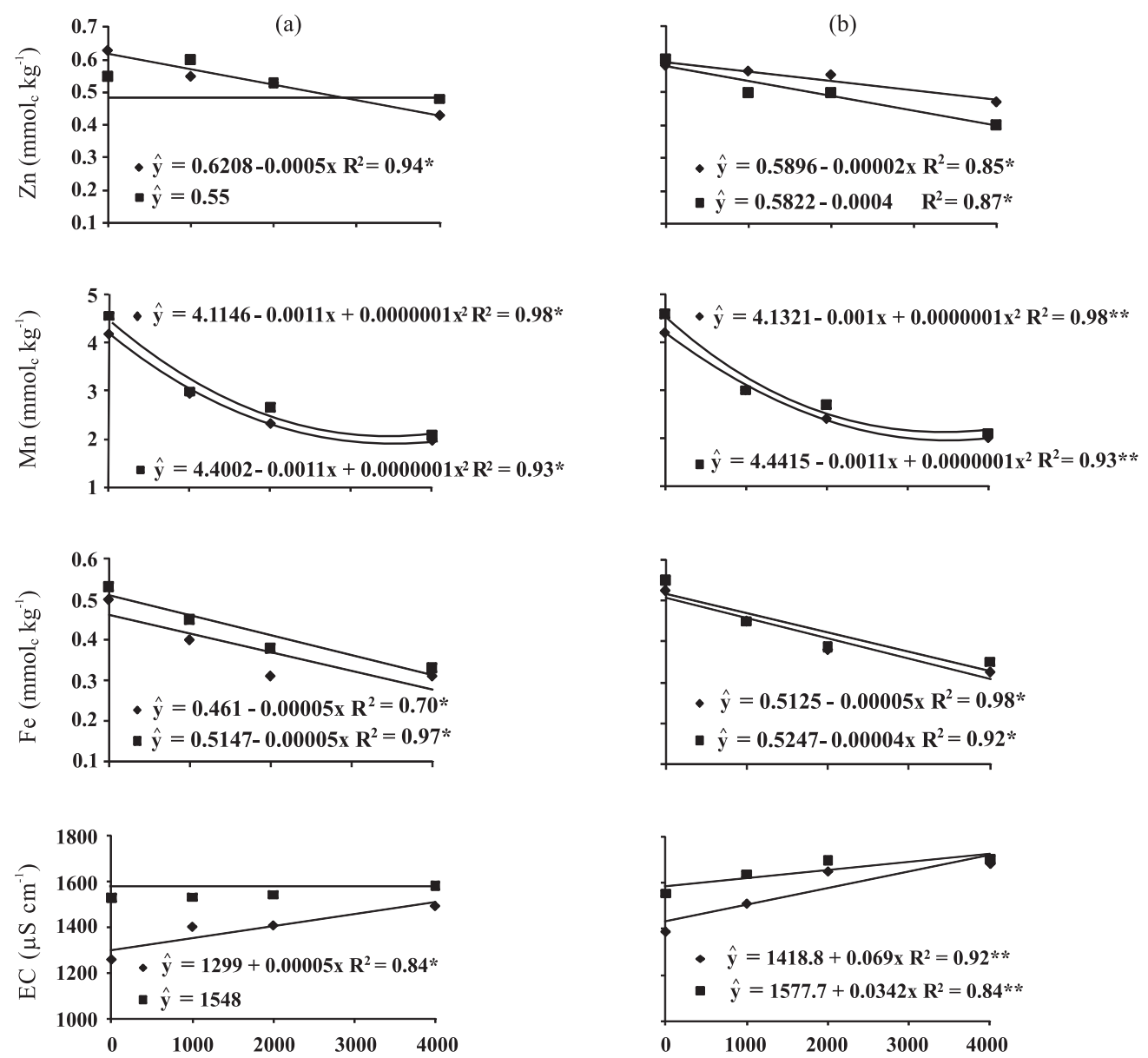

$\operatorname{LIME}\left(\mathrm{kg} \mathrm{ha}^{-1}\right)$

Figure 2. Contents of water-soluble zinc, manganese and iron and electrical conductivity (EC) in plant extracts of flowering peanut, as related to surface liming . ( $\square$ ) without gypsum and ( $\downarrow$ ) with gypsum in 2004/2005 (a) and 2005/2006 (b).

Table 3. Contents of water-soluble nutrients and electrical conductivity (EC) in the white oat extract at flowering as related to application or non-application of gypsum to the soil surface in 2004/2005 and $2005 / 2006$

\begin{tabular}{|c|c|c|c|c|c|c|c|c|c|}
\hline & Treatment & $\mathbf{C a}$ & $\mathrm{Mg}$ & $\mathbf{K}$ & Mn & $\mathrm{Zn}$ & $\mathrm{Cu}$ & $\mathrm{Fe}$ & EC \\
\hline \multirow{4}{*}{ 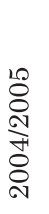 } & Gypsum & \multicolumn{7}{|c|}{$\mathrm{mmol}_{\mathrm{c}} \mathrm{kg}^{-1}$} & $\mu \mathrm{S} \mathrm{cm} \mathrm{cm}^{-1}$ \\
\hline & Without & 52.0 & $74.6 \mathrm{a}$ & 27.8 & 2.2 & 0.55 & 0.37 & 0.48 & 838 \\
\hline & With & 54.2 & $59.3 \mathrm{~b}$ & 27.7 & 2.1 & 0.33 & 0.33 & 0.46 & 790 \\
\hline & $\begin{array}{l}\mathrm{CV}_{1}(\%) \\
\mathrm{CV}_{2}(\%)\end{array}$ & 12.3 & $\begin{array}{l}7.1 \\
9.2\end{array}$ & $\begin{array}{l}12.3 \\
10.7\end{array}$ & $\begin{array}{l}17.4 \\
11.8\end{array}$ & 29.4 & 18.4 & 14.8 & $\begin{array}{l}3.3 \\
8.3\end{array}$ \\
\hline \multirow{4}{*}{ 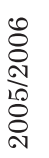 } & Without & 47.9 & $68.2 \mathrm{a}$ & 25.6 & 2.0 & 0.30 & 0.33 & $0.45 \mathrm{a}$ & $806 a$ \\
\hline & With & 508 & $549 \mathrm{~b}$ & 256 & 19 & 034 & 031 & $039 \mathrm{~b}$ & $763 b$ \\
\hline & $\mathrm{CV}_{1}(\%)$ & 15.7 & 12.4 & 13.3 & 16.1 & 32.4 & 22.5 & 18.5 & 6.3 \\
\hline & $\mathrm{CV}_{2}(\%)$ & 11.9 & 12.7 & 12.4 & 14.6 & 19.7 & 15.0 & 17.6 & 5.9 \\
\hline
\end{tabular}

(1) Sum. Means followed by different letters, in the column, differ statistically by the DMS test $(p=0.05)$. CV ${ }_{1}$ : Coefficient of variation of the plots; $\mathrm{CV}_{2}$ : Coefficient of variation of the subplots.

the contents and increased availability of these cations in the soil, which led to higher contents of the soluble nutrients in the aerial plant parts of oat.
Liming decreased $\mathrm{Zn}, \mathrm{Mn}$ and Fe contents in the 2005 growing season, decreased Mn and Fe contents in 2006 and did not affect Zn contents in the second 

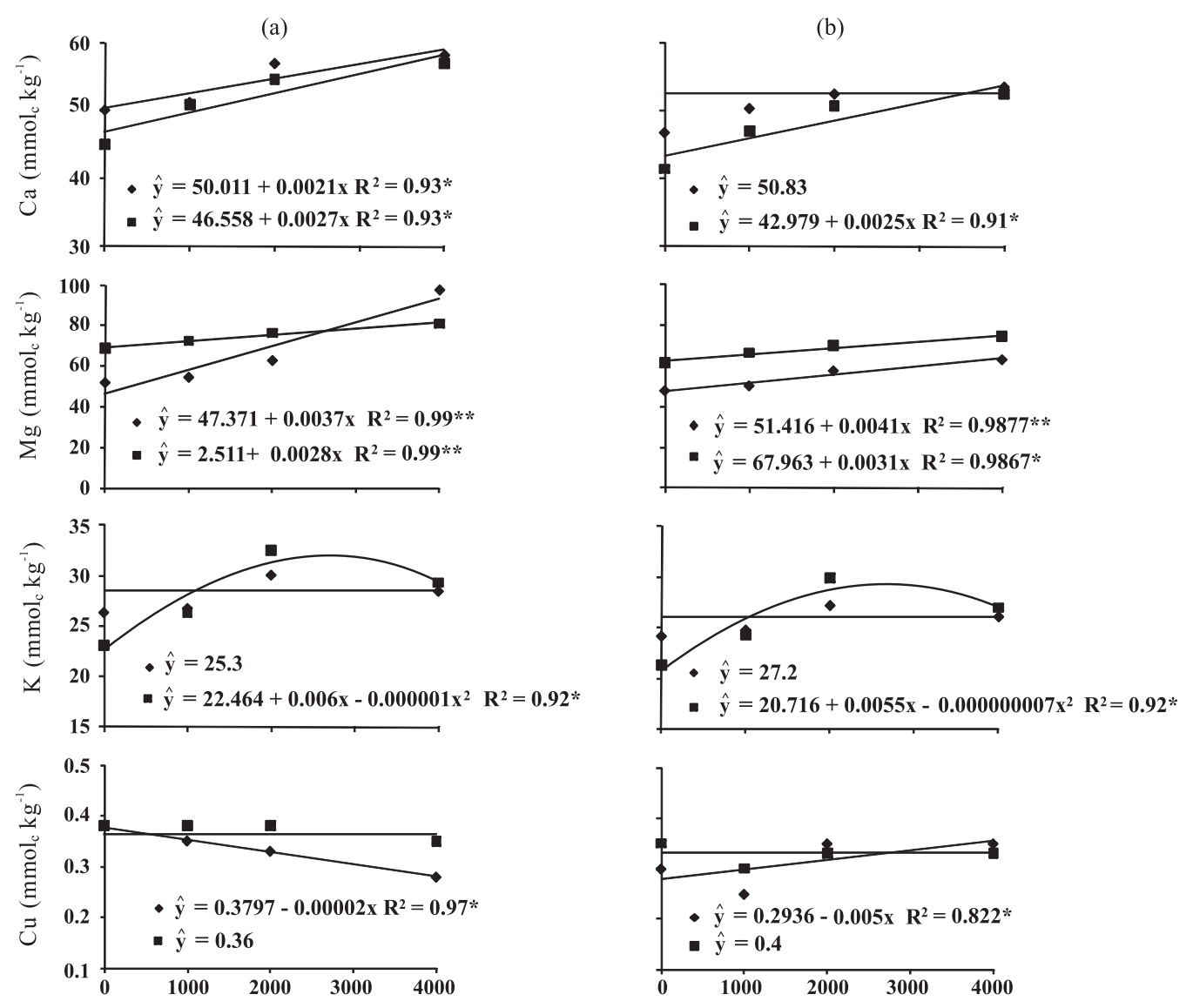

LIME $\left(\mathrm{kg} \mathrm{ha}^{-1}\right)$

Figure 3. Contents of water-soluble calcium, magnesium potassium and copper in plant extracts of white oat at flowering as related to surface liming. ( $\square$ ) without gypsum and ( $\downarrow)$ with gypsum in 2004/2005 (a) and 2005/2006 (b).

growing season (Figure 4), as similarly observed for peanut (Figure 2).

As for most nutrients, a significant interaction was observed for the EC in the extract of white oat in both growing seasons (Figure 4) under lime - gypsum application. This indicates that the sum of watersoluble in the aerial plant parts can be correlated with the electrical conductivity of the plant extracts, the evaluation of the latter is less costly and faster and can therefore be used as a parameter of the capacity of plant material to complex toxic $\mathrm{Al}$ or enhance the cation leaching in no-tillage (Franchini et al., 1999a; Miyazawa et al., 2002).

It is worth mentioning, that similarly to the effects of species (Meda et al., 2002b; Miyazawa et al., 2000), cultivar (Cassiolato et al., 2000), and plant growth stage (Franchini et al., 2003) on the capacity of plant residues to influence the soil nutrient movement, lime and gypsum applications, which have proved to be highly important for the management of soil acidity under no-till, can also affect this property (Soratto \& Crusciol, 2007).

There is wide variation in the chemical composition of plant species (Meda et al., 2002a, Lima, 2004) for water-soluble $\mathrm{Ca}, \mathrm{Mg}$ and $\mathrm{K}$. In peanut the contents of these elements were higher than in oat (Table 4). This high content of $\mathrm{H}$ and $\mathrm{Al}^{+}$can be neutralized by plant residues of peanut, since the $\mathrm{Ca}, \mathrm{Mg}, \mathrm{K}, \mathrm{Mn}, \mathrm{Zn}, \mathrm{Cu}$, and $\mathrm{Fe}$ cations bound in organic compounds are replaced by $\mathrm{H}$ or $\mathrm{Al}^{3+}$, forming stable protonated compounds or Al-organic complexes (Miyazawa et al., 2000).

According to Miyazawa et al. (1993) and Franchini et al. (2001) residues of cash crops have on average only one third of the neutralizing capacity of cover crops. This lower capacity to neutralize the soil acidity of residues of crops such as soybean, wheat and maize is related to the reduction in soluble nutrient and $\mathrm{C}$ contents with the advancing physiological plant age (Franchini et al., 2004). However, it is noteworthy that the plants in this study were sampled to determine soluble cations at flowering, which is a stage of high metabolic activity. Most likely, this factor contributed to the high contents of water-soluble basic reaction nutrients observed in peanut. It is however unclear whether these nutrients were complexed to the plant or released into the soil during the crop cycle; further studies on the dynamics of these compounds within the plant are required. 

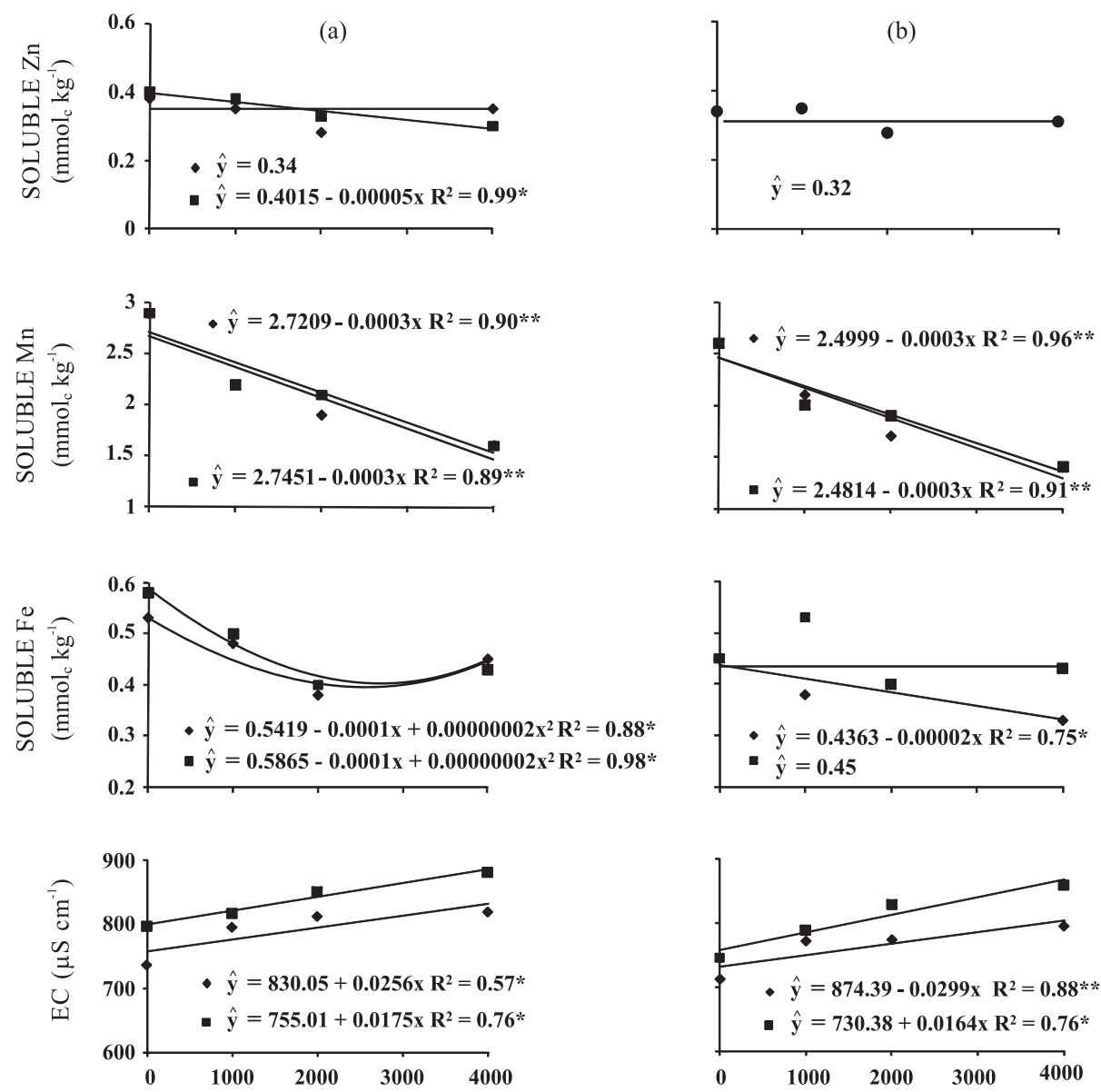

LIME $\left(\mathrm{kg} \mathrm{ha}^{-1}\right)$

Figure 4. Contents of zinc, manganese, iron, and electrical conductivity (EC) in white oat at flowering, as related to surface liming. (O) mean of the treatments with and without gypsum application, ( $\square)$ without gypsum and ( $\diamond$ ) with gypsum in 2004/2005 (a) and 2005/2006 (b).

Table 4. Contents of water-soluble nutrients and electrical conductivity (EC) in the plant extract of peanut and white oat at flowering in $2004 / 2005$ and $2005 / 2006$

\begin{tabular}{|c|c|c|c|c|c|c|c|c|}
\hline Crop & $\mathbf{C a}$ & Mg & $\mathbf{K}$ & Mn & $\mathrm{Zn}$ & $\mathbf{C u}$ & $\mathbf{F e}$ & EC \\
\hline & & & 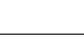 & $\mathrm{ckg}^{-1}$ & & & - & $\mu \mathrm{S} \mathrm{cm}^{-1}$ \\
\hline $\begin{array}{l}\text { Peanut }(2004 / 2005) \\
\text { White oat }(2005)\end{array}$ & $\begin{array}{r}152.7 \\
53.1\end{array}$ & $\begin{array}{r}290.3 \\
63.9\end{array}$ & $\begin{array}{l}52.4 \\
27.8\end{array}$ & $\begin{array}{l}3.0 \\
2.1\end{array}$ & $\begin{array}{l}0.5 \\
0.3\end{array}$ & $\begin{array}{l}0.5 \\
0.3\end{array}$ & $\begin{array}{l}0.4 \\
0.5\end{array}$ & $\begin{array}{r}1471.4 \\
813.9\end{array}$ \\
\hline Peanut $\quad(2005 / 2006)$ & 155.7 & 296.3 & 53.6 & 3.0 & 0.5 & 0.4 & 0.4 & 1602.6 \\
\hline White oat (2005) & 49.4 & 61.6 & 25.6 & 2.0 & 0.3 & 0.3 & 0.4 & 784.5 \\
\hline
\end{tabular}

According to Franchini et al. (2004), plant residues with high contents of water-soluble Ca have a greater capacity to immobilize $\mathrm{Al}^{3+}$. Thus, the effect of peanut residues in reducing $\mathrm{Al}^{3+}$ in the soil is expected to be greater.

The water-soluble nutrient contents in the plant extracts were ranked in decreasing order: $\mathrm{Mg}>\mathrm{Ca}>$ $\mathrm{K}>\mathrm{Mn}>\mathrm{Fe}>\mathrm{Zn}>\mathrm{Cu}$. This probably occurred by $\mathrm{K}$ washing by the intense rain in the summer of 2004/ 2005 and 2005/5006, in the tissue of the aerial plant parts under field conditions (Rosolem et al., 2003), since the sampled biomass had not been washed with distilled water and dried for later analysis.

Although the water-soluble nutrient contents were lower in oat than peanut, it is known that peanut produces great contents of residues per unit area. 
Besides, the crop is generally handled in the full vegetative growth phase for purposes of green manure and straw production for sustainability of no-tillage.

The results of this study show the relationship of EC in the extract with the contents of water-soluble nutrient of plant residues of both species evaluated in two growing seasons, in agreement with results of Franchini et al.(1999a). Opposite to peanut, EC for oat was lower in the plant extract, due to the lower content of nutrients in solution. Therefore, EC in plant extracts, measurable in a simpler and cheaper way, indicates the content of nutrients in solution. These values can be used to predict the quality of plant material used in no-tillage.

\section{CONCLUSIONS}

1. Gypsum application to peanut increased watersoluble nutrients $\mathrm{Ca}$ in the plant only in the first season, which was attributed to the short period between the application of the product and determination of soluble nutrient contents in the plant extract.

2. Liming of peanut and white oat increased water $\mathrm{Ca}, \mathrm{Mg}, \mathrm{K}$ contents, but did not alter the water $\mathrm{Cu}$ content and reduced $\mathrm{Zn}, \mathrm{Mn}$ and Fe water contents in both years of cultivation.

3. Gypsum reduced the EC in peanut and white oat extract.

\section{LITERATURE CITED}

AMBROSANO, J.E.; TANAKA, R.T.; MASCARENHAS, H.A.A.; RAIJ, B.van; QUAGGIO, J.A. \& CANTARELLA, H. Leguminosas e oleaginosas. In: RAIJ, B.van; CANTARELLA, H.; QUAGGIO, J.A. \& FURLANI, A.M.C., eds. Recomendações de adubação e calagem para o Estado de São Paulo. 2.ed. Campinas, Instituto Agronômico de Campinas/Fundação IAC, 1996. p.189-203. (Boletim Técnico, 100)

CAIRES, E.F.; BLUM, J.; BARTH, G.; GARBUIO, F.J. \& KUSMAN, M.T. Alterações químicas do solo e resposta da soja ao calcário e gesso aplicados na implantação do sistema de plantio direto. R. Bras. Ci. Solo, 27, 2:275-286, 2003.

CAIRES, E.F.; KUSMAN, M.T.; BARTH, G.; GARBUIO, F.J. \& PADILHA, J.M. Alterações químicas do solo e resposta do milho à calagem e aplicação de gesso. R. Bras. Ci. Solo, 28:125-136, 2004.

CAMARGO, C.E.O.; FREITAS, J.G. \& CANTARELLA, H. Aveia e centeio. In: RAIJ, B.van; CANTARELLA, H.; QUAGGIO, J.A. \& FURLANI, A.M.C., eds. Recomendações de adubação e calagem para o Estado de São Paulo. Campinas, Instituto Agronômico de Campinas, 1996. p.5253. (Boletim Técnico, 100).
CASSIOLATO, M.E.; MEDA, A.R.; PAVAN, M.A.; MIYAZAWA, M. \& OLIVEIRA, J.C. Evaluation of oat extracts on the efficiency of lime in soil. Braz. Arch. Biol. Technol., 43:533536,2000

CASSIOLATO, M.E.; MIYAZAWA, M.; MEDA, A.R. \& PAVAN, M.A. A laboratory method to estimate the efficiency of plant extract to neutralize soil acidity. Braz. Arch. Biol. Technol., 45:183-187, 2002.

FERREIRA, D.F. Análise estatística por meio do SISVAR para Windows versão 4.0. In: REUNIÃO ANUAL DA REGIÃO BRASILEIRA DA SOCIEDADE INTERNACIONAL DE BIOMETRIA, 45., 2000, São Carlos. Anais. São Carlos, UFSCar, 2000. p.255-258.

FRANCHINI, J.C. Influência de resíduos vegetais na toxidez de $\mathrm{Al}$ e na mobilidade de íons no solo. In: REUNIÃO BRASILEIRA DE FERTILIDADE DO SOLO E NUTRIÇÃO DE PLANTAS, 26., Lages, 2004. Anais... Lages, SBCS/UDESC, 2004. CD ROM.

FOOD AND AGRICULTURE ORGANIZATION OF THE UNITED NATIONS - FAO. World Soil Resources Report. FAO, Rome, 2006. (World reference base for soil resources, 103)

FRANCHINI, J.C.; HOFFMANN-CAMPO, C.B.; TORRES, E.; MIYAZAWA, M. \& PAVAN, M.A. Organic composition of green manures during growth and its effect on cation mobilization in an acid Oxisol. Comm. Soil Sci. Plant Anal., 34:2045-2058, 2003.

FRANCHINI, J.C.; MALAVOLTA, E.; MIYAZAWA, M. \& PAVAN, M.A. Alterações químicas em solos ácidos após a aplicação de resíduos vegetais. R. Bras. Ci. Solo, 23:533$542,1999 a$.

FRANCHINI, J.C.; MEDA, A.R.; CASSIOLATO, M.E.; MIYAZAWA, M. \& PAVAN, M.A. Potencial de extratos de resíduos vegetais na mobilização do calcário no solo por métodos biológico. Sci. Agric., 58:357-60, 2001.

FRANCHINI, J.C.; MIYAZAWA, M.; PAVAN, M.A. \& MALAVOLTA, E. Dinâmica de íons em solo ácido lixiviado com extratos de resíduos vegetais de adubos verdes e soluções puras de ácidos orgânicos. Pesq. Agropec. Bras., $34: 2267-2276,1999 \mathrm{~b}$

GALON, J.A.; BELLINGIERI, P.A. \& ALCARDE, J.C. Efeito de modos e épocas de aplicação de gesso e calcário sobre a cultura do feijoeiro (Phaseolus vulgaris L.) cv. Carioca80. Sci. Agric., 53:119-125, 1996.

HARMSEN, K. \& VLEK, P.L.G. The chemistry of micronutrients in soil. Fert. Res., 7:1-42, 1985.

LIMA, E.V. Plantas de cobertura e calagem superficial na fase de implantação do sistema de plantio direto em região de inverno seco. Botucatu, Universidade Estadual Paulista, 2004. 125p. (Tese de Doutorado)

LOMBARDI NETO, F. \& DRUGOWICH, M. Manual técnico de manejo e conservação de solo e água. Campinas, CATI, 1994. v.2. 168p.

MEDA, A.R.; CASSIOLATO, M.E.; PAVAN, M.A. \& MIYAZAWA, M. Alleviating soil acidity through plant organic compounds. Braz. Arch. Biol. Technol., 44:185189,2001 
MEDA, A.R.; PAVAN, M.A.; CASSIOLATO, M.E. \& MIYAZAWA, M. Dolomite limes reaction applied on the surface of a sandy soil of the Northwest Paraná, Brasil. Braz. Arch. Biol. Technol., 45:219-222, 2002a.

MEDA, A.R.; PAVAN, M.A.; MIYAZAWA, M. \& CASSIOLATO, M.E. Plantas invasoras para melhorar a eficiência da calagem na correção da acidez subsuperficial do solo. R. Bras. Ci. Solo, 26:647-654, 2002b.

MENEGALE, M.L.C.; CASTRO, G.S.A. \& CRUSCIOL, C.A.C. Efeito da aplicação de corretivos do solo nos teores de cátions hidrossolúveis de extratos vegetais de aveia. In: FERTBIO 2008, Londrina. Anais. Londrina, 2008. CDROM.

MIYAZAWA, M.; PAVAN, M.A. \& CALEGARI, A. Efeito de material vegetal na acidez do solo. R. Bras. Ci. Solo, 17:411416, 1993.

MIYAZAWA, M.; PAVAN, M.A. \& FRANCHINI, J.C. Evaluation of plant residues on the mobility of surface applied lime. Braz. Arch. Biol. Technol., 45:251-256, 2002.

MIYAZAWA, M.; PAVAN, M.A. \& FRANCHINI, J.C. Neutralização da acidez do perfil do solo por resíduos vegetais. Inf. Agron., 92:1-8, 2000.
QUAGGIO, J.A.; DECHEN, A.R. \& RAIJ, B.van. Efeito da aplicação de calcário e gesso sobre a produção de amendoim e lixiviação de bases no solo. R. Bras. Ci. Solo, 6:189-194, 1982.

PIERRE, W.H. \& BANWART, W.L. Excess-base and excessbase/nitrogen ratio of various crop species and parts of plants. Agron. J., 65:91-96, 1973.

RAIJ, B.van; ANDRADE, J.C.; CANTARELLA, H. \& QUAGGIO, J.A. Análise química para avaliação da fertilidade de solos tropicais. Campinas, Instituto Agronômico de Campinas, 2001. 284p.

ROSOLEM, C.A.; CALONEGO, J.C. \& FOLONI, J.S.S. Lixiviação de potássio da palha de espécies de cobertura do solo de acordo com a quantidade de chuva aplicada. R. Bras. Ci. Solo, 27:355-362, 2003.

SORATTO, R.P. \& CRUSCIOL, C.A.C. Cátions hidrossolúveis na parte aérea de culturas anuais mediante aplicação de calcário e gesso em superfície. R. Bras. Ci. Solo, 31:81-90, 2007. 